\title{
SLC12A7 wt Allele
}

National Cancer Institute

\section{Source}

National Cancer Institute. SLC12A7 wt Allele. NCI Thesaurus. Code C124990.

Human SLC12A7 wild-type allele is located in the vicinity of 5p15 and is approximately 62 $\mathrm{kb}$ in length. This allele, which encodes solute carrier family 12 member 7 protein, is involved in cellular homeostasis. 